\title{
Videoobservation
}

\section{- et empirisk blik på undervisning}

\author{
Rune Hansen, lektor, ph.d.-studerende, ruha@ucsyd.dk \\ og Dorthe Carlsen, lektor, ph.d-studerende, dcar@ucsyd.dk. \\ UCSYD og Aarhus Universitet
}

\begin{abstract}
Resumé
I denne artikel diskuteres, hvordan man kan undersøge undervisning som et empirisk genstandsfelt. Artiklen falder i to dele. I første del diskuteres empirisk undersøgelse af undervisning i forhold til det aktuelle uddannelsespolitiske fokus på "den empiriske vending". "Den empiriske vending" har sat fokus på undersøgelse af undervisning i et bestemt metodisk perspektiv og med henblik på effektivisering af undervisning og uddannelse. Det er imidlertid forsimplet, hvis man reducerer al empirisk skoleforskning til effektforskning. Der er andre formål med og måder at bedrive empirisk didaktisk forskning på. Som et eksempel herpå introduceres i anden del professor David Clarkes fire perspektiver på videoobservation, og gennem konkrete eksempler diskuteres, hvordan man kan observere undervisning i fag på den ene side med blik for undervisningens kompleksitet og på den anden side med viden om forskningsdesign og -redskabers formaterende kraft. Ved at introducere Clarkes fire perspektiver vises, at både kvantitative og kvalitative undersøgelsesformer kan have deres berettigelse i undersøgelse af et vildt og komplekst fænomen som undervisning, men også at ikke mindst kvalitativ klasserumsforskning kræver stor metodisk dømmekraft, idet forskeren i situationen må kunne foretage en række metodiske valg, vel vidende at disse får afgørende betydning for såvel analysemuligheder som undersøgelsens udsigelseskraft.
\end{abstract}

\section{Nøgleord}

Videoobservation, empirisk undersøgelse, kvantitativ/kvalitativ metode, empirisk vending, evidens

\section{Den empiriske vending}

Efter "TIMMS-chokket" og "PISA-katastrofen" er der inden for
uddannelsesforskningen sket en afgørende empirisk vending.
Orienteringen mod påviselige virkninger er kommet for at blive.
Skole og undervisning må lade sig måle på, hvilket udbytte ele-

Årg. 2 | nr. 1 | 2017 | Side 47-72 | https://tidsskrift.dk/index.php/SLP/index 


\section{verne beviseligt får. (...) Ligesom ingen læge vil gennemføre behandlinger uden forudgående anamnese og diagnose, har vi i skolen brug for en velfunderet dokumentation som grundlag for pædagogiske indsatser (Helmke, 2013, s. 13).}

Sådan indleder den tyske empiriske uddannelsesforsker Andreas Helmke sin bog Undervisningskvalitet og lærerprofessionalitet. Diagnosticering, evaluering og udvikling af undervisning. Citatet udtrykker kernen i det, der i dag kaldes "den empiriske vending" i uddannelsesforskningen. Undervisningsobservation udgør en særlig grundpille i Helmkes empiriske forskningstilgang. Han ser undervisningsobservation som en modsætning til en normativ teoretisk forskningstilgang. Modsætningen mellem en empirisk og en normativ pædagogisk videnskab fremhæves også ofte i Danmark. Spørgsmålet er, om det ikke er en falsk modsætning. Ligger der ikke altid i det empiriske arbejde - implicit eller eksplicit - værdier, forestillinger og en teori om, hvad undervisning (det empiriske genstandsfelt) er?

Den aktuelle interesse for påviselige effekter hænger sammen med et internationalt uddannelsespolitisk fokus på effektivitet i uddannelsessystemer - PISA og TIMMS er eksempler herpå. Den finske uddannelsesforsker Pasi Sahlberg beskriver denne tendens som GERM-effekten - Global Education Reform Movement - og karakteriserer den som en reformortodoksi, der er præget af tendenser som fokus på kernekompetencer (fx læsning og matematik, der måles i internationale sammenlignende undersøgelser som fx PISA) og søgning efter evidente metoder til at nå læringsmål (lav-risiko-metoder, hvor der ikke er frihed til at eksperimentere med alternative pædagogiske tilgange) (Sahlberg, 2012). I Danmark ses dette bl.a. i Folkeskolereformen fra 2013, hvor man som noget nyt opstillede resultatmål for elevernes læring og folkeskolens udvikling (Fagligt løft af folkeskolen, 2013). Resultatmålene er kvantificerbare mål for elevernes læring, der kan bruges som et redskab til at vurdere skolen og udbyttet af den investering, som samfundet gør heri. Når eleverne skal blive så dygtige, som de kan (på en given skala og i sammenligning med andre elever på andre skoler og i andre lande), og både elever og skolevæsener måles herpå, er det ikke overraskende, at evidens og kravet om evidensbaseret undervisning dukker op. Professionelle lærere har en selvfølgelig interesse $i$ at øge den viden, de funderer deres undervisning på. Men det er en særlig type viden og uddannelsesforskning, der hen- 
Hansen og Carlsen: Videoobservation

vises til, nemlig evidensbaseret forskning, hvor empiri især genereres som kvantitative data med fokus på objektivering og generalisering.

\section{Mellem empiri og normativitet}

I opposition til den empiriske uddannelsesforskning i ovenstående betydning står en normativ filosofisk-pædagogisk tradition. At dømme efter engagerede debatter på platforme som folkeskolen.dk står de stejlt over for hinanden. Folkeskolen.dk er et debatforum og ikke et akademisk kritisk forum, men diskussioner mellem lærere, lægmænd, forskere og undervisere viser, at der er noget væsentligt og essentielt på spil i kløften mellem de 'objektive' empirikere og de normative pædagoger. På folkeskolen.dk opsummeres i december 2016, at artiklen "Afsløring: Ingen evidens for, at læringsmålstyret undervisning virker" om Keld Skovmands bog Uden mål og med - forenklede Fælles Mål (Skovmand, 2016) var årets næstmest læste artikel og den tredjemest debatterede (Olsen, 2016). Debatten handlede om mål over for formål, dannelse over for kompetence, undervisning over for læring, måling over for dømmekraft, den empiriske vending over for pædagogisk filosofi og så videre. Stefan Hermanns bog Hvor står kampen om dannelsen? (2016) er ligeledes et eksempel på krigen mellem to positioner. Herman skriver $\mathrm{i}$ indledningen: "Min påstand er, at den afgørende strid i dansk uddannelse i disse år er en kamp om dannelsen, og at denne kamp udkæmpes mellem to positioner, der gør hinanden dummere frem for at kvalificere sig i striden" (Hermann, 2016, s. 5). De to positioner benævnes henholdsvis "den pædagogisk-konservative position" og "den politisk-administrative position". I Almen didaktik markerer Alexander von Oettingen med undertitlen - mellem evidens og normativitet - et forsøg på at bygge bro mellem en evidensbaseret og en normativ tilgang til almendidaktik (Oettingen, 2016), men i mellemrummet fastholdes evidens og normativitet samtidig som modpoler.

Når man skelner mellem empirisk objektiv og ikke-empirisk normativ pædagogisk forskning, placeres empirisk pædagogisk forskning i en naturvidenskabeligt orienteret kausalitetsforskning med videnskabsteoretiske tråde til positivisme, empirisme og realisme. Hvis man løsriver empirisk pædagogisk forskning fra "den empiriske vending", opdager man imidlertid, at empirisk forskning kan bedrives på vidt forskellige måder og med vidt forskellige intentioner. En del empirisk pædagogisk forskning er inspireret af en hermeneutisk og antropologisk tradition, som trækker videnskabsteoretiske tråde til fænomenologien og eksistensfilosofien. 
I "den empiriske vending" fokuseres på forholdet mellem input og output med henblik på at identificere hvilke pædagogiske metoder, der virker bedst (global evidens og effektivitet). Når Helmke sammenligner pædagogisk forskning med lægevidenskab, risikerer man at reducere undervisning til et middel, der sigter på at øge et målbart læringsudbytte. Det interessante bliver, hvor meget har eleverne lært, ikke hvad. I den forstand er den empiriske vendings blik på undervisningen et ikke-normativt blik: man forholder sig ikke til fx indholdsvalg og -kvalitet, men fokuserer på det størst mulige udbytte (læringskvantitet). Heroverfor står den normative pædagogiske filosofi, som insisterer på at diskutere kvalitative træk ved undervisningen. I den forstand er de to positioner uforenelige. Men det forsimpler også diskussionen om empirisk skoleforskning, fordi skellet risikerer at reducere al empirisk skoleforskning til effektforskning. Og det er en reduktion, som hverken aktuelt eller historisk er konstruktiv.

\section{Empirisk skoleforskning i historisk perspektiv}

Der er i Danmark såvel som i andre lande en lang tradition for at arbejde med en systematisk videnskabelig udvikling af undervisning. Historiske nedslag viser, at pædagogisk empirisk forskning også nationalt har svinget mellem en positivistisk orienteret og en humanistisk orienteret forskning (Gjerløff et al., 2014, s. 118-125).

Anne Marie Nørvig, der fra 1948 til 1959 var leder af Emdrupborg forsøgsskole, beskriver tre typer af forsøgsskoler i sin samtid: 1) eksperimentelle skoler, hvor virkningen af forskellige metoder undersøges empirisk, 2) demonstrationsskoler, hvor forskellige metoder demonstreres under optimale forhold, dvs. frigjort fra traditioner og kommunale undervisningsplaner, 3) en nøgtern og realistisk progressiv skole, der skaber balance mellem hensynet til barnets frihed og ydre krav (Gjerløff et al., 2014, s. 209-213). Fælles for forsøgene var, at de byggede på en overbevisning om en bedre pædagogisk praksis inspireret af fx Jean-Jacques Rousseau eller John Deweys tanker. Allerede for 100 år siden udtrykte lærere og myndigheder skepsis i forbindelse med en omfattende pædagogisk forskning med henblik på at nå objektive resultater (Skovmand, 1977, s. 100), hvilket på sæt og vis spejler den nutidige interesse for, men også tvivl og modstand over for forestillingen om objektive, evidente resultater.

Med folkeskoleloven af 1958 blev mulighederne for etablering af forsøgsundervisning eksplicit beskrevet i Den Blå Betænkning. Det beskrives, at det 
både er forventeligt og ønskværdigt, at en lærer afprøver nye tiltag i undervisningen. I betænkningen fremhæves dog "egentlige skoleforsøg", der sigter mod at generere objektive resultater. Gennem syv punkter beskrives en række krav til udvikling af et systematisk opbygget og kontrolleret skoleforsøg. Det positivistiske paradigme for vidensproduktion skinner tydeligt igennem. I 1969 udgiver Kaj Spelling, professor i eksperimentel pædagogik ved Danmarks Lærerhøjskole en artikel, hvori han skelner mellem to forsøgsformer i skolen: pædagogisk udviklingsarbejde og systematiske forsøg, samtidig med at han gør opmærksom på, at der er tale om en form for flydende overgang mellem de to forsøgsformer, da det ideelle systematiske skoleforsøg er en illusion (Skov, 2005). Fra efterkrigstiden og frem oprettes og nedlægges en række råd, der har til formål at støtte vidensudviklingen i og om folkeskolen ${ }^{1}$. I en analyse af rådenes udvikling skriver Poul Skov:

\section{Det er imidlertid værd at overveje, om udviklingen er ved at gå i retning af, at man ikke er tilstrækkelig opmærksom på betyd- ningen af lokale ideer, initiativer og erfaringer. Det ønskelige må være, at udviklingen kan bygge på såvel centrale initiativer og undersøgelser som på initiativer og erfaringer fra det store vækst- lag af engagerede personer, der findes på skoler over hele landet (Skov, 2005, s. 64).}

Normativ eller empirisk, kvantitativ eller kvalitativ, lokal eller global, evidens-hierarki eller evidens-typologi - set i et historisk perspektiv synes et af problemerne ved den aktuelle empiriske vending ikke at være, hvorvidt man arbejder kvantitativt eller kvalitativt, lokalt eller globalt. Dilemmaer som disse er relevante i ethvert undersøgelsesdesign. Det historiske rids viser, at på det metodiske plan er der en lang tradition for kvantitative og kvalitative empiriske undersøgelser (ved siden af teoretiske studier). Forandringen synes ikke at ligge i hoad (undervisning som empirisk genstandsfelt) eller hvorfor (udvikling af praksis), men snarere i hvorfra. Hvorfra spørges? Hvad er det for en pædagogisk eller didaktisk tænkning, undersøgelsesdesignet operationaliserer? Hvor henter undersøgelsen sin stemme og sit pædagogiske, didaktiske eller fagdidaktiske blik?

1 Center for Strategisk uddannelsesforskning (www. cser.dk) og Nationalt center for skoleforskning (www.ncs.au.dk) kan også ses som led i denne bevægelse. 


\section{Vilde eller tamme problemer?}

Når Helmke og andre sammenligner undervisning med lægevidenskab eller tandfyldning, gøres undervisning til et tamt problem. Hvis man studerer plastfyldinger eller sammenhængen mellem bremseskiver og trafikulykker, giver det god mening at teste og måle. Men ét af problemerne ved "den empiriske vending" er, at den behandler undervisning og læring, som om det var bremseskiver og plastfyldinger. Selv om det er forførende at sammenligne fx læsehastighed med bremselængder, giver det ikke nødvendigvis et meningsfuldt billede af eller indsigt $i$, hvad det vil sige, og hvad det kræver at kunne læse med dybde, forståelse, empati og kritik. Eller indblik i, hvordan forskellige børn i forskellige kontekster bliver læsere. Professor Hanne Kathrine Krogstrup skelner mellem vilde og tamme problemer (Krogstrup, 2006, s. 26). Det kræver meget komplicerede beregninger at udvikle bremseskiver og at bygge en Storebæltsbro, men det er muligt at udregne den for tiden mest optimale løsning på problemet. Det er et "tamt" problem. Undervisning er et vildt problem (Krogstrup, 2011, s. 95).

Når man tæmmer vilde problemer ved at skabe indikatorer og tælle op, risikerer man at miste blikket for undervisningens kompleksitet. Projektet "Program for forskningsinformeret, målstyret skole- og kompetenceudvikling" er et eksempel på et projekt, der arbejder med omfattende datamængder med henblik på skoleudvikling ${ }^{2}$. Programmets mål er, at de deltagende skoler efterlever skolereformens mål om, at de skal udfordre alle elever, så de bliver så dygtige, som de kan (www.laeringsledelse.dk). I rapporterne for de enkelte kommuner er en lang indledning, der også rummer henvisninger til en pædagogisk tradition (fx Egelund, Aasen, Nordahl \& Qvortrup, 2016, s. 16). Som læser fornemmer man, at det dels giver undersøgelsen legitimitet og dels svarer på hvorfor, men det synes ikke at være et afsæt for hvorfra, der spørges. Eller sagt på en anden måde: Den pædagogiske teori legitimerer undersøgelsen, mens det er langt vanskeligere at se, hvordan den pædagogiske teori informerer undersøgelsen og indgår i undersøgelsens operationelle definitioner.

I programmet gennemføres tre store kvantitative målinger (initialt, midtvejs og ved programmets afslutning efter fire år), der skal være med til at

2 A.P. Møller-fonden bevilligede i efteråret 201421 mio..kr. til programmet, der ledes af Laboratorium for forskningsbaseret skoleudvikling og pædagogisk praksis, som i dag er rykket til Nationalt Center for Skoleforskning, Aarhus Universitet. I programmet deltager $13 \mathrm{kommu}-$ ner. Man kan læse mere om programmet og dataindsamlingen på www.laeringsledelse.dk. 
dokumentere, om målet nås. Gennem surveys indsamles data fra seks kilder: Elever, klasselærere, forældre, lærere, pædagoger og skoleledelse (Qvortrup, Egelund \& Nordahl, 2016), ved at disse kilder på en fire- eller femtrinsskala skal erklære sig mere elle mindre enige i en lang række udsagn. Data bygger således på kildernes oplevede vurderinger af faglig og social trivsel og læring. Outputtet af kortlægningen er en læringsrapport for hver kommune, som præsenterer en lang række statistiske beregninger af kildernes oplevede trivsel og læring. Men rapporterne kan ikke sige noget om, hvad i den eksisterende praksis der gør, at elever $\mathrm{fx}$ trives eller mistrives. Fx viser rapporten for en af de deltagende kommuner: "at Svendborg Kommune med variationer på fra 502 til 498 point statistisk set ligger inden for gennemsnitsintervallet på fra 495 til 505 point for samtlige 13 kommuner, når det gælder de tre trivselsområder" (Egelund, Aasen, Nordahl \& Qvortrup, 2016, s. 46). Men hvad bliver man egentlig klogere på? Trives eleverne? Det gør sig vel kun gældende, hvis de også trives i de andre deltagende kommuner. Eller hvad kan man konkludere, når elever i 0.-3. klasse svarer på en firetrinskala i forbindelse med spørgsmål som "Jeg kan godt lide at gå i skole", og gennemsnittet bliver 3,56? På hvilken måde støtter og guider det lærere i at navigere i undervisningens kompleksitet og udøve professionel dømmekraft? I et interview formulerer Lars-Henrik Schmidt det således: "Det er Qvortrups øvelse: „Tallene siger!“ (...) Det er som om, tallene er blevet subjekt” (Schmidt, 2016, s. 10). Og man kunne tilføje, at tallene kommer til at fremstå, som om der er tale om objektive kendsgerninger - og ikke forskellige kilders oplevede trivsel og læring.

Tals beskrivelseskraft er ofte så stor, at de rummer en fare for forførelse. Når der er fokus på forenklede beskrivelser med afsæt i et omfattende datamateriale, kan det hurtigt forføre én til skrøbelige kausale forklaringer. Jo mere undervisningens kompleksitet sammenfattes til et tal, desto vigtigere er det at forholde sig til de begrænsninger, en sådan beskrivelse rummer. Kan egenskaber virkelig beskrives på en skala fra 1 til 4? - og er det en lineær eller eksponentiel skala? Den vilde virkelighed forsvinder gradvist med stigende abstraktion. Problemet er ikke nødvendigvis, at man tæller, men lige så meget, hvad man bruger disse tal til. Banalt sagt er der stor forskel på at måle med henblik på sammenligning og konkurrence - og at måle med henblik på didaktisk udvikling. Det påtrængende spørgsmål er således, hvilke data og hvilken viden hvem har brug for til hvilket formål - altså sammenhængen mellem en undersøgelses intention (beskrive, forklare, forstå, forandre) og metode. Det hænger også sammen med, hvilket 
perspektiv der anlægges: top-down eller bottom-up (Krogstrup, 2006, s. 138 ff.). I et top-down-perspektiv er man som fx beslutningstager eller skoleejer (legitimt) interesseret $\mathrm{i}$ at vide, om noget virker og har effekt (value for the money); i et bottom-up-perspektiv er man (legitimt) optaget af at vurdere, om man er på rette spor, om der er brug for justeringer eller at gå andre didaktiske veje. Spørgsmålet er, hvor langt ind i klasserummet de legitime ønsker om effekt rækker. Derfor bliver spørgsmålet om evidens og evidente metoder centralt.

\section{Den empiriske vending $i$ undervisningen}

Den empiriske vending hænger tæt sammen med et ønske om at øge effekten af samfundets investering i skolen. Man forestiller sig at kunne destillere den bedste vej - og dernæst implementere denne $\mathrm{i}$ al undervisning - $\mathrm{i}$ princippet globalt. Det er groft sagt ideen i forestillingen om evidensbaseret undervisning. Martyn Hammersley (2004) hævder, at selve betegnelsen evidensbaseret undervisning er et slogan, hvis retoriske virkning er at miskreditere modstandere heraf. Hvem kan være uenige $i$, at læreres undervisningspraksis skal baseres på den bedste viden og forskningsresultater? Inspireret af den medicinske verden er et dominerende perspektiv, at evidens skal frembringe svar. Svar, der kan hjælpe lærerne til at gøre tingene bedre (Elliott, 2004).

Dette perspektiv på evidens problematiseres imidlertid af flere (Biesta, 2011; Elliott, 2004). Gary Thomas (2004) nuancerer ved at minde om, at evidens kan antage forskellige former og blive værdisat forskelligt inden for forskellige fagområder. Når det drejer sig om, "hvad der virker" i undervisningssammenhænge, peger Thomas på begrebet intuition. Intuition knytter sig til en personlig, tavs viden, der er dannet af oplysninger - data, beviser - akkumuleret både bevidst og tilfældigt om verden. I lærerens undervisningspraksis opstår nye ideer ofte ud fra en fornemmelse af, at en bestemt måde måske er den rigtige måde at gøre noget på. Evidens er i denne forståelse også lærerens eksperimenter med input og data fra hverdagen og derfor mere end "bare" forskningsresultater (Thomas, 2004). Også Michael Eraut (2004) interesserer sig for praktikeren som såvel evidensskabende som evidensbrugende. Han sætter fokus på evidens som et datadrevet arbejde, hvor læreren gennem deltagende observation, elevprodukter, forskellige evalueringsformer m.m. genererer data og får etableret et vidensgrundlag, som vedkommende kan handle ud fra. Lærere må således overveje både, hvor- 
dan de vil fremstille data, hvordan dette influerer på den undervisningsmæssige kontekst (konstitutive virkninger), og hvordan de vil bruge både egne data og forskningsviden i undervisningen.

I en dansk kontekst trænger kravet om empiri sig også på i læreruddannelsen, idet den lærerstuderende "skal udarbejde et skriftligt professionsbachelorprojekt med udgangspunkt i en konkret empirisk problemstilling, hvori inddrages resultater fra konkrete forsknings- og udviklingsprojekter og forskningsbaseret litteratur inden for grundskoleområdet. Problemstillingen skal tage afsæt $\mathrm{i}$ folkeskolens praksis eller praksis fra andre skoleformer" (Uddannelses- og Forskningsministeriet, 2015). Dette arbejde med empiri kan tolkes enten som et skridt i retning af den empiriske vending med fokus på læringsudbytte, eller man kan læse det som et forsøg på at kvalificere dels læreruddannelsens arbejde med undervisning i skolen på en nuanceret og mangefacetteret måde både teoretisk og empirisk, og dels at uddanne læreren til i sit virke at være evidensproducerende og -brugende i Erauts forstand.

\section{Videoobservation - forskellige blikke på undervisning}

I denne del af artiklen zoomer vi ind på videoobservation som en måde at generere data på. Vi introducerer til lederen af det internationale center for klasserumsstudier (ICCR) ${ }^{3}$ professor David Clarkes fire perspektiver på videoobservation, og gennem små eksempler vises, at dataindsamlingsmetoder ikke er neutrale, ligesom forskerens metodiske dømmekraft er væsentlig.

Observation er blot en blandt mange måder at generere data på. Når man vil arbejde empirisk, kan man grundlæggende spørge mennesker (spørgemetoder), iagttage mennesker (observationsmetoder) eller indsamle forskellige ting og tekster (dokument- eller genstandsmetoder). Selve datagenereringsmetoden knytter ikke i sig selv an til et bestemt videnskabsteoretisk ståsted eller til kvantitative eller kvalitative undersøgelsesformer. Alle måder at producere data på må tænkes sammen med formålet med undersøgelsen (beskrive, forklare, forstå, forandre). Ved empirisk skoleforskning er man forpligtet på eksplicit at argumentere for valg af teori og metodiske tilgange, så andre får mulighed for at vurdere korrespondancen mellem intention og metode. 
I Tabel 1 Videoobservation i forskellige forskningstyper ${ }^{4}$ anskueliggøres, at videoobservation ikke er et neutralt medie, men kan fungere i og understøtte forskellige forskningstyper med forskellige forskningsmæssige intentioner. Dette uddybes med introduktionen til Clarkes fire perspektiver på video.

Tabel 1. Videoobservation i forskellige forskningstyper

\begin{tabular}{|c|c|c|}
\hline $\begin{array}{l}\text { Forskningstype } \\
\text { og -formål }\end{array}$ & Kvantitativ metode & Kvalitativ metode \\
\hline Beskrive & $\begin{array}{l}\text { Video som vindue } \\
\text { Objektivt blik ind i undervisnin- } \\
\text { gen med henblik på at beskrive } \\
\text { de kvantitative træk, der foku- } \\
\text { seres på i undersøgelsen, fx } \\
\text { hvor mange gange forekommer } \\
\text { dette eller hint i undervisnin- } \\
\text { gen, som grundlag for sam- } \\
\text { menligning eller opstilling af } \\
\text { hypoteser. }\end{array}$ & $\begin{array}{l}\text { Video som linse } \\
\text { Blik i og på undervisningen } \\
\text { med henblik på at beskrive de } \\
\text { kvalitative træk, der fokuseres } \\
\text { på i undersøgelsen, fx hvem } \\
\text { gør hvad hvordan i undervis- } \\
\text { ningen. }\end{array}$ \\
\hline Forklare & $\begin{array}{l}\text { Video som } \\
\text { forvrængende spejl } \\
\text { Video bruges til at få så righol- } \\
\text { dige data som muligt med hen- } \\
\text { blik på at efterprøve hypoteser } \\
\text { og søge forklaringer og årsags- } \\
\text { sammenhænge. }\end{array}$ & \\
\hline Forstå & & $\begin{array}{l}\text { Video som linse eller som } \\
\text { forvrængende spejl } \\
\text { Videoen er en forlængelse og } \\
\text { fastholdelse af forskerens blik, } \\
\text { der zoomer ind og ud, vender, } \\
\text { drejer og følger - med henblik } \\
\text { på at forstå menneskelige } \\
\text { udtryk og handlinger i kontek- } \\
\text { sten. }\end{array}$ \\
\hline Forandre & $\begin{array}{l}\text { Video som katalysator } \\
\text { Undersøgelse af bestemte } \\
\text { undervisningsmæssige fæno- } \\
\text { mener, hvor deltagerne gennem } \\
\text { brugen af video stimuleres til at } \\
\text { eksperimentere med bestemte } \\
\text { variable i undervisning. }\end{array}$ & $\begin{array}{l}\text { Video som katalysator } \\
\text { Video anvendes til at etablere } \\
\text { et refleksionsrum, hvor delta- } \\
\text { gere kan få øje på - og dermed } \\
\text { mulighed for at eksplicitere } \\
\text { perspektiver med henblik på } \\
\text { at forandre praksis. }\end{array}$ \\
\hline
\end{tabular}


Hansen og Carlsen: Videoobservation

\section{Observation}

Observation kan vælges, når man er interesseret $\mathrm{i}$, hvordan mennesker handler i forskellige sammenhænge. I observation er fokus på de direkte aflæselige træk ved situationen, herunder deltagernes interaktion med det materielle og sociale miljø (Raudaskoski, 2010, s. 82). Observation gør det muligt at beskrive, hvad der foregår, hvem og hvad der er involveret, hvor og hvornår, hvordan sociale processer og handlinger gøres i tid og rum. Observation giver overordnet mulighed for at se, hvad mennesker gør, mens observationen ikke giver adgang til det, mennesker tænker.

Når man beslutter sig for at observere, er der en række valg, man må foretage, fx valg af observationssted (klasseværelse eller laboratorium - se afsnittet Video som forvrængende spejl), og observationstilgang. Observationstilgangen kan være åben eller skjult, deltagende eller ikke-deltagende, struktureret eller ustruktureret - og alle mellemvarianter. Disse valg hænger sammen med forskerens videnskabsteoretiske ståsted, fx kan man diskutere, om man overhovedet kan tale om ikke-deltagende observation. Ud fra et hermeneutisk perspektiv kan man argumentere for, at alene det, at man er til stede, gør, at man er deltagende.

Der findes allerede meget metodelitteratur. Observation anvendes inden for mange videnskabelige retninger og med mange videnskabelige formål. I Danmark har der været forsket en del i brugen af video som undervisningsog læremiddel, men der er ikke ret meget nyere dansk litteratur om videoobservation som forskningsmetode og -redskab. Vores bidrag til mængden af metodelitteratur er med afsæt i David Clarke og kollegaers forskning at stille nogle greb til rådighed, som kan diskuteres på (mindst) tre niveauer: videnskabsteoretisk, i forhold til konkrete, unikke undersøgelsesdesign og som metode til produktion af data. Målet er at supplere og bidrage til et blik på blikket og en reflekteret omgang med videoobservation med særligt henblik på undervisning som empirisk genstandsfelt.

\section{Videoobservation}

Video bruges som dokumentationsredskab i forbindelse med observation. Men video er ikke bare et neutralt dokumentationsredskab. Qua sine tekniske affordances (men også begrænsninger) er videomediet med til at formatere de data, der genereres. Helle Alrø og Marianne Kristiansen (1997) skriver om videoen, at den er god til at fastholde noget, der i princippet for- 
svinder i det øjeblik, det finder sted, og fremhæver, at den største fordel ved videoen er, at den giver mulighed for at fange det, der foregår både auditivt og visuelt. Det er således muligt at fastholde både verbale og nonverbale udtryk (Alrø \& Kristiansen, 1997, s. 73). Med videoen kan man skabe en multimodal tekst. Alligevel er der også noget, videoen ikke kan indfange, fx lugte og fornemmelser i situationen, og derfor er det vigtigt at erindre, at videoklippet ikke er lig med virkeligheden (Alrø \& Kristiansen, 1997, s. 76). En af videomediets affordances er, at det fastholder alle handlinger i optagefeltet også dem, der ikke umiddelbart påkalder sig opmærksomhed, og som forskeren måske ikke i første omgang hæfter sig ved og noterer i sine feltnoter, men som ved senere analyser kan vise sig at fange fx rutinerede eller ritualiserede handlinger (Jank \& Meyer, 1997). Dirckinck-Holmfeld beskriver, at videomediet bl.a. af denne grund må betragtes som "et meget væsentlig medium i forhold til at fastholde handlinger og fremanalysere erfaringer" (Dirckinck-Holmfeld, 1997, s. 109).

Når man spørger, om videoobservation kan adskilles fra den eller de, der gør observationerne i felten, vil det kvalitative svar være, at det er vanskeligt. Set fx i et fænomenologisk perspektiv kan den kropslige sansning og tilstedeværelse være helt central, bl.a. fordi den sansede oplevelse i situationen danner grundlaget for de første intuitive tolkninger (Rønholt, 2003, s. 119). Se også afsnittene Video som linse og Video som katalysator. Set fra et positivistisk perspektiv betragtes videoen som en neutral eller objektiv gengivelse af det sete ud fra de på forhånd kendte og opstillede præmisser. Se afsnittet Video som vindue nedenfor.

\section{Analyse}

Analysen begynder egentlig allerede i designet af undersøgelsen gennem de valg, der foretages. Selve analysestrategien må korrespondere med det samlede undersøgelsesdesign. Har man valgt en beskrivende, forklarende eller forandrende forskningstype med brug af kvantitativ metode, må man foretage sine analyser i overensstemmelse hermed. Det vil sige ved brug af statistiske modeller og beregninger og afhængigt af de enkelte variables måleniveauer. Man kan gå deskriptivt eller induktivt til værks afhængigt af forskningsinteresse (Thisted, 2010). Også i en kvalitativ undersøgelse begynder analysen allerede i de valg, man træffer i situationen, når man står med sit videokamera og fx vælger at zoome ind på en bestemt deltager. I praksis 
sker der løbende en vekselvirkning mellem "indsamling" og analyse. Analysen kan være enten datadrevet eller teoridrevet (Thisted, 2010, s. 175-6). I det kvalitative analytiske arbejde kan man overordnet følge Steinar Kvales analysetrin til interviewanalyse, som giver mening i forhold til kvalitativ analyse i det hele taget (Brinkmann \& Kvale, 2008, s. 217-218). Et andet bud på en systematik findes hos Alrø og Kristiansen (1997), der anvender følgende niveauer i videoanalysen: intuition, iagttagelse, oplevelse, identifikation, argumentation og diskussion, fortolkning, mønstre og strategier. En af udfordringerne ved videoanalyse er spørgsmålet om, hvorvidt man skal transskribere videoen til tekst som første analysetrin og eventuelt hvordan. Der findes ikke faste anvisninger herpå, og et af problemerne er blandt andet hvordan og i hvilken udstrækning, man skal forsøge at transskribere det ikke sagte - kroppene i rummet, lyde osv. (Alrø \& Kristiansen, 1997; Dirckinck-Holmfeld, 1997; Rønholt, 2003). En måde at løse det på er ved at arbejde med multimodale tekster, hvor læseren både kan læse den transskriberede tekst og se videoklippet (illustreres senere i denne artikel).

\section{Vindue, linse, forvrænget spejl, katalysator}

David Clarke (2015) skelner mellem fire mulige metaforer for videoens medierende rolle i forbindelse med klasserumsforskning:

- Som et vindue, hvorigennem forskeren ser klasserummet

- Som en linse, hvorigennem forskeren fokuserer på udvalgte aspekter ved aktiviteter i klasserummet

- Som et forvrængende spejl, hvor forskeren ikke så meget ser en repræsentation af klasserummet, men snarere en afspejling af vedkommendes egne værdier og perspektiver rekonstrueret som klasserumsdata

- Som en katalysator, hvor der fx etableres refleksionsrum med henblik på at forandre praksis.

I det følgende vil vi udfolde de forskellige beskrivelser, deres metodiske konsekvenser og betydning for de forskningsresultater, man producerer. 


\section{Video som vindue}

Man kan se video som et vindue ind i klasselokalet. Der er fokus på, hvad forskeren objektivt "ser". Clarke, Mitchell, og Bowman (2009) betoner, at det er først, når forskeren kan se situationer i klasserummet fra alle deltageres perspektiv, at han/hun kan begynde at forstå den motivation og de holdninger, der ligger til grund for deres deltagelse i undervisningen. Den metodiske konsekvens er, at videokameraet skal kunne optage alle lærere og elever i klasserummet. Metaforen er ofte relateret til kvantificerbare elementer i undervisningen, hvor man er optaget af at sammenligne forskellige klasserum med hinanden som udgangspunkt for at forme og teste forskellige hypoteser. Her får observationen en beskrivende karakter, hvor forskeren eksempelvis kan lave optællinger i forhold til antallet af lærer- og elevytringer eller brugen af faglige begreber i plenumsamtaler. Noget sådan har David Clarke (2010) undersøgt i en international klasserumsundersøgelse.

Hvem taler? (antallet af ytringer)

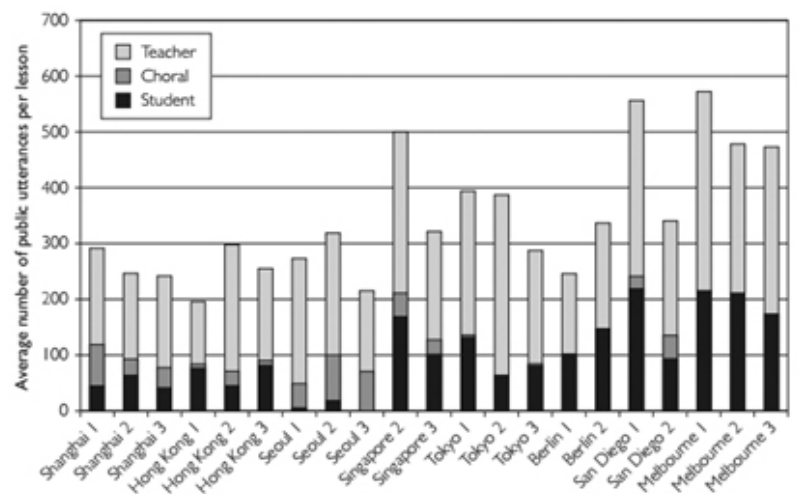

Hvad taler de om? (faglige begreber)

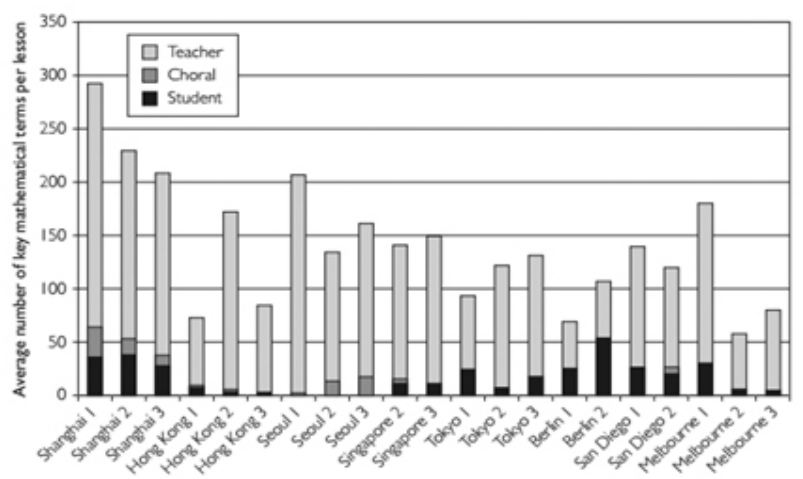


I video som vindue forstås videoen som en neutral videnskilde, der fordomsfrit gengiver undervisningen. Tilgangen har en stærk tilknytning til traditionen med strukturerede observationer og observationsskemaer inden for empirisk pædagogiske forskning, hvor eksempelvis Ned Flanders og Edmund Amidon tilbage i 1960'erne har udviklet observationsskemaer med fokus på interaktionen blandt lærer og elever i klasserummet (Amidon, 1966). Helmke (2013, s. 234-247) viderefører denne tradition ved at introducere forskellige observationsskemaer, der kan understøtte en struktureret observation. Højstrukturerede og systematiske observationsstudier fokuserer (som i de ovennævnte tilfælde) ofte på hyppigheden af en specifik adfærd (aktivitetsoptegnelser) eller varigheden af en bestemt adfærd i en lektion (varighedsoptegnelser).

Videofastholdelsen gør det modsat real time-kodning muligt at gense sekvenser og diskutere kodninger. Ved kodning af video kan skelnes mellem to kodningstyper: dækkende og forekommende koder. Dækkende koder har mindst to gensidigt udelukkende koder, hvor kun en af disse muligheder kan anvendes i et bestemt tidsrum. Hvis der eksempelvis er fokus på elevers arbejdsform, kan dækkende kode være individuelt arbejde, makkerpar eller gruppearbejde Det bevirker, at der altid vil være et begyndelsespunkt og et slutpunkt for en sådan kode. Forskere i TIMSS 1999 Video Study har blandt andet anvendt dækkende koder til at kode matematiklektioner i deres helhed (Jacobs et al., 2003). Den udviklede kodningsmanual giver indblik i det omfattende kodningsarbejde (TIMSS-R Video Math Coding Manual). Det er ikke muligt at beskrive alt med dækkende koder, hvorfor der også kan anvendes forekommende koder. Med forekommende koder markeres, hver gang koden optræder i en lektion. Det kan eksempelvis være en udefrakommende forstyrrelse, som at der bankes på døren, og en forælder kommer ind i lokalet.

Hvad enten forskeren benytter video eller observationsskemaer, fremkommer der udvendige og abstrakte billeder af klasserummet. Det kan give fejlagtige billeder af skolen, som kan vildlede andre (Lindblad \& Sahlström, 2003). Det er derfor væsentligt at forholde sig kritisk til observationer af det vilde fænomen undervisning, når denne beskrives gennem undervisningsobservationer.

Når video anvendes som et vindue ind i klasserummet, etableres muligheden for en større transparens i forbindelse med de indikationer, som forskeren udvælger og efterfølgende forholder sig til. Ved strukturerede real time-observationer har læsere ingen mulighed for at verificere undersøgel- 
sens resultater. De kan udelukkende forholde sig til designet af observationsskemaet samt anvendelsen af dobbeltscoringer. Dobbeltscoringer anvendes til at underbygge validiteten og reliabiliteten af observationsskemaet, hvor to observatører uafhængigt af hinanden udfylder (scorer) observationsskemaet. Ved at bruge video som vindue ind i klasserummet etableres muligheden for, at læsere kan se videoen og derved forholde sig til forskerens kodninger. Hvis forskeren tilslutter sig et naturvidenskabeligt orienteret forskningsparadigme, er transparensen ved brug af video selvsagt at foretrække.

\section{Video som linse}

Video kan også anskues som en linse. Her fokuseres på bestemte begivenheder i undervisningen, som forskeren zoomer ind på. En konsekvens heraf er, at andet udelades. Forskeren skaber altså forholdene eller perspektivet gennem sin udvælgelse. Derfor bliver video også et forskningsredskab, som forskeren udnytter strategisk til at skabe bestemte billeder af klasserummet og undervisningen. Det betyder, at de billeder (data), som skabes af undervisning, hovedsagelig er baseret på forskerens strategiske valg. Dermed er denne brug en selektiv og konstrueret repræsentation af undervisningen. Clarke et al. (2009) beskriver, hvordan enhver beslutning om eksempelvis at zoome ind på en lærer/elev i undervisningen eller dreje videokameraet repræsenterer en bevidst handling fra forskerens side i forsøget på at konstruere et datasæt, der på bedst mulig måde kan hjælpe med at besvare forskningsspørgsmålene. Forskeren er styrende for datagenereringen, og videooptagelserne udgør en selektiv og konstrueret repræsentation af undervisningen.

Modsat video som vindue er der fokus på data, der fremkommer med righoldige detaljer af undervisningens vilde problemer. Som beskrevet i tabel 1 tager det afsæt i kvalitative metoder, hvor forskeren på eksempelvis etnografisk vis får mulighed for at besvare spørgsmål som, hvad gør læreren, hvad gør eleverne, hvordan arbejder de med faget. Der har i Danmark historisk set været en tradition for denne type "feltforskning" under betegnelser som klasserumsforskning, aktionsforskning og forskningsbaseret forsøgs- og udviklingsarbejde (Skov, 2005).

I Runes projekt "Målstyret kompetenceorienteret matematikundervisning" (Hansen, 2016) anvendes video som en linse. Der er tale om en longitudinal etnografisk inspireret undersøgelse med fokus på én lærer og én 
klasse i grundskolen i en toårig periode. Rune har haft adgang til et videokamera og en mikrofon. I forbindelse med ugentlige klasserumsoptagelser placeres videokameraet, så det kan optage tavlen, læreren og størstedelen af eleverne ved plenumsamtaler.

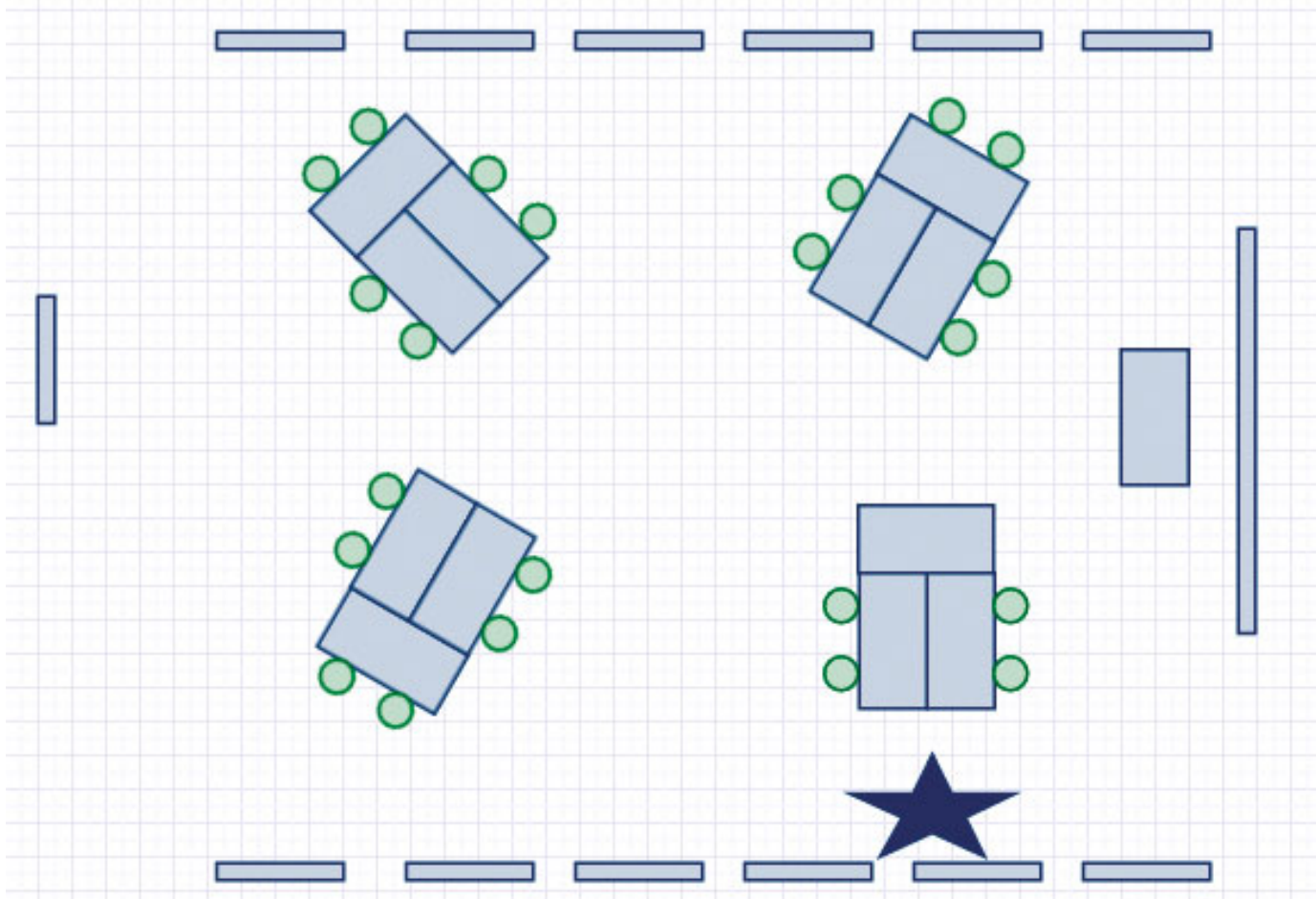

Ved elevernes arbejde med matematiske aktiviteter udvælges - i udgangspunktet - en gruppe i det enkelte forløb, der følges med videokameraet. Her zoomer Rune ind på elevernes læringsaktiviteter, også når læreren ikke er til stede. Et alternativ ville være at følge læreren med et videokamera. Det fravalgtes allerede i begyndelsen, da det kan virke meget forstyrrende i forhold til den daglige undervisningspraksis. Det er et eksempel på, hvordan forskeren gennem sine valg er med til at skabe et bestemt perspektiv, hvor en række elementer udelades.

Et eksempel på video som linse er en undervisningssekvens, hvor der zoomes ind på fire elevers interaktion med hinanden, matematiklæreren og nedenstående opgave Transskription af en undervisningssituation kan ikke være objektiv, da den hviler på overvejelser over forholdet mellem detaljeringsgrad og overskuelighed. I denne artikel har vi valgt at fokusere på 


\section{overskuelighed, samtidig udnytter vi den multimodale tekstproduktion ved at give læseren mulighed for at se videoklippet ${ }^{5}$.}

(1) a Drengen og pigen på vippen er ikke ens. Hvorfor er vippen mon så i ligevægt? b Hvis de smider deres tasker, er vippen stadig i ligevægt. Hvad må der gælde om de to taskers vægt?

(2) Hvad vil der ske med ligevægten, hvis a man kaster en liter malk op til hver af dem? b de skifter plads på et mikrosekund? c pigen hopper af?

d man kun kaster en liter mælk op til pigen?

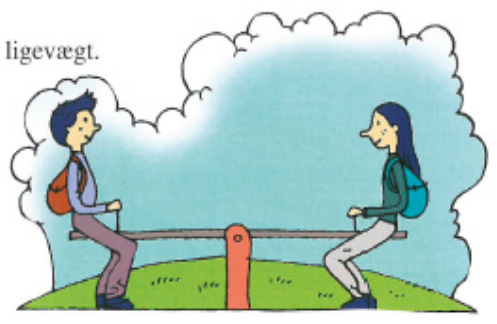

Vi kommer ind i situationen umiddelbart efter, eleverne er blevet bedt om at gå i gang med opgaverne, der er i elevernes matematikbog. De to piger og den ene dreng sidder med bog og hæfte slået op og kigger på siden. Den sidste dreng rejser sig og vender kort efter tilbage med sin matematikbog.

Elev22 begynder straks at tale om, hvad han iagttager på billedet: "Hvorfor de vejer det samme? Fordi de har benene på jorden."

Elev6 begynder at tale til Elev16, der dog har fokus på opgaven i matematikbogen, og svarer drengen: "Ja, fordi de har benene på jorden. Det er faktisk rigtig."

Elev22 svarer: "De har benene på jorden, det er derfor, der ikke sker noget."

Elev22 fortsætter med at læse op: "Hvis de smider deres tasker, ville der så stadig være ligevægt? Ja."

Samtidig spørger Elev16, hvad Elev 6 har skrevet. Hun svarer: "Jeg har skrevet, de vejer lige meget."

Elev22 gentager, hvad han sagde før, og Elev16 siger: "De har benene på jorden, det er vel det."

Elev22 svarer og læser videre i opgaven: "Ja, det er sådan, hvis de smider deres tasker er vippen stadig i ligevægt. Ja, fordi de har samme taske på."

Elev16 svarer: "Nej, jeg tror, man skal sige det, som om de vejer lige meget."

Elev7 kommer tilbage til den videoobserverede bordgruppe efter at have hentet matematikbogen i sin skuffe. Læreren giver samtidig en besked til klassen. 
Elev16 henvender sig til Elev6 og fortæller, at hun er ved at have brugt sit hæfte. Herefter finder de to piger blyanter frem. Elev6 kigger i bogen sammen med Elev7, hvorefter hun læser opgave 1.a. op: "Hvorfor er vippen mon så i ligevægt?"

Elev22 svarer: "Ja det betyder, at hvorfor er den så lige. Det er på grund af, at de har benene på jorden."

Elev6 siger: "Så vi kan skrive [utydeligt]."

Elev7 sidder og kigger på billedet på den anden side i matematikbogen, hvorefter han siger: "De er begge to kvinder."

Elev6 ignorerer dette og siger: "Men jeg tror, altså ikke. Tror I, det er meningen, at de har benene på jorden?"

Elev16 svarer: "Jeg tror, det er fordi, de vejer lige meget."

Herefter bliver Elev6 opmærksom på, at Elev7 kigger på den forkerte side. Hun hjælper ham til at fokusere på den rigtige opgave. I samtalen når eleverne frem til, at de to personer vejer det samme. Matematiklæreren står og observerer elevernes samtale. På et tidspunkt vender eleverne tilbage til deres oprindelige undren.

Elev22 siger: "Nej, jeg tror bare, de mener, at det er sådan - ham der vejer mere end hende der - men på grund af deres tasker, så vejer de det samme."

Matematiklæreren sætter sig nu på hug ved det videoobserverede bord.

Elev22 kigger kort på hende, hvorefter han retter blikket mod matematikbogen og siger: "Men det er også bare det der med, at de har benene på jorden. Det er sikkert derfor, at de står lige."

Elev6 siger: "Jamen jeg tror ikke, det er meningen, de har benene på jorden."

Elev16 svarer: "Nej, jeg tror, de vejer lige meget."

Elev7 siger: "Jeg tror, det bare er noget, man skal ignorere."

Matematiklæreren går ind i samtalen ved at sige: "Det kan I så vælge og sige. At I ignorerer, at de har benene på jorden, og derfor er det her gældende."

Elev22 svarer: "Altså jeg gætter på, hvad det er, opgaven vil have, vi skal. At det er fordi, sådan de er ikke ens, det betyder, at en af dem vejer mere, end den anden gør."

Eleverne fortsætter med opgaveløsningen, mens matematiklæreren rejser sig og forlader bordgruppen. 
Ved at anvende Alrø og Kristiansens analysemodel beskrives sammenhængen mellem observation og analyse. I selve undervisningssituationen overværer Rune gruppens samtale. Intuitivt har han på fornemmelsen, at der er et eller andet i situationen, som er værd at forfølge. Efterfølgende ser han videooptagelsen af lektionen og finder frem til ovenstående sekvens. Sekvensen genses flere gange, og han iagttager, hvem der siger og gør hvad i situationen. Alrø og Kristiansen (1997) beskriver dette som en ydre sansning. Samtidig er han bevidst om sin egen oplevelse af situationen, hvor han er opmærksom på sine mulige fordomme mod lærebøger (indre sansning). På baggrund af iagttagelserne og oplevelserne begynder han at zoome ind på særlige elementer ved situationen. Et særligt fokus i forskningsprojektet er sammenhængen mellem mål, opgaver og elevernes matematiske læring. I undervisningssekvensen er der tydelige indikationer på en form for nedbrud i elevernes samtale, hvor de gentagne gange prøver at tilskrive mening til opgaven. For at forstå situationen henter Rune hjælp i teorier om læsning af multimodale fagtekster, der fremhæver betydningen af, at de forskellige modaliteter understøtter hinanden. På grund af artiklens omfang vil vi ikke videreføre denne diskussion, men derimod fortolke situationen således, at opgaven skaber en situation, hvor den af læreren opbyggede didaktiske forbindelse mellem mål, opgaver og elevers matematiske læring ikke etableres på grund af en problematisk opgaveformulering.

Her fungerer video som en linse, der fastholder forskerens blik, som vender og drejer situationen med henblik på at forstå elevernes og lærerens udtryk og handlinger i situationen. Analysen og fortolkningen bliver afhængig af forskerens perspektiv og defineret af de forskningsspørgsmål, vedkommende søger svar på. Brug af video giver forskeren mulighed for at arbejde med en form for asynkront observeret virkelighed, hvor han/ hun kan gå tilbage og se eller gense særlige sekvenser, som vedkommende mener, kan bidrage til en eller anden analytisk pointe. Men video er ikke et neutralt medie! I forhold til ovenstående undervisningssekvens skaber Runes valg en situation, hvor videokameraet indfanger en - for ham - interessant samtale. Men ville han også have fanget samtalen, hvis han havde valgt at følge matematiklæreren med et kamera eller havde placeret kameraet i et hjørne? Hvad ville man få ud af at placere to, tre eller fire kameraer i klasserummet? Og hvilke udfordringer ville noget sådant rumme? 


\section{Video som forvrængende spejl}

Video kan også ses som et forvrængende spejl. Her former den teoretiske ramme datasættet. Forskerens teoretiske position er udgangspunkt for dannelsen af det specifikke datasæt. Tidligere var der en række teknologiske begrænsninger forbundet med at repræsentere de komplekse dimensioner ved undervisning, men nu er det muligt at skabe et righoldigt datamateriale, hvor kombinationer af begivenheder, artefakter og mennesker gør det muligt, at forskellige forskere kan analysere den samme undervisningssituation, men at de "forvrænger" datasættet i forhold til de handlinger og motiver i undervisningen, som de søger at forstå (Clarke et al., 2011). Video kan bruges til at efterprøve hypoteser og søge forklaringer og årsagssammenhænge, men det er også muligt at etablere en forhandling af mening med afsæt i forskellige teoretiske positioner for netop at forstå undervisning som et vildt problem. Hvor forskeren med afsæt i brugen af video som linse kan "nøjes" med et lille antal videokameraer, foreskriver denne tilgang et væsentligt større teknisk beredskab, som på helt anden vis kan indfange undervisningens kompleksitet. Det kan eksempelvis være et særligt indrettet laboratorium som ICCR's videoovervågede klasserum ${ }^{6}$, hvor der er 16 videokameraer og 32 mikrofoner. Klasserummet kan indrettes på forskellige måder, og forskere har mulighed for at observere undervisningen bag et envejsspejl med en kontrolpult, som styrer kameraer og mikrofoner.

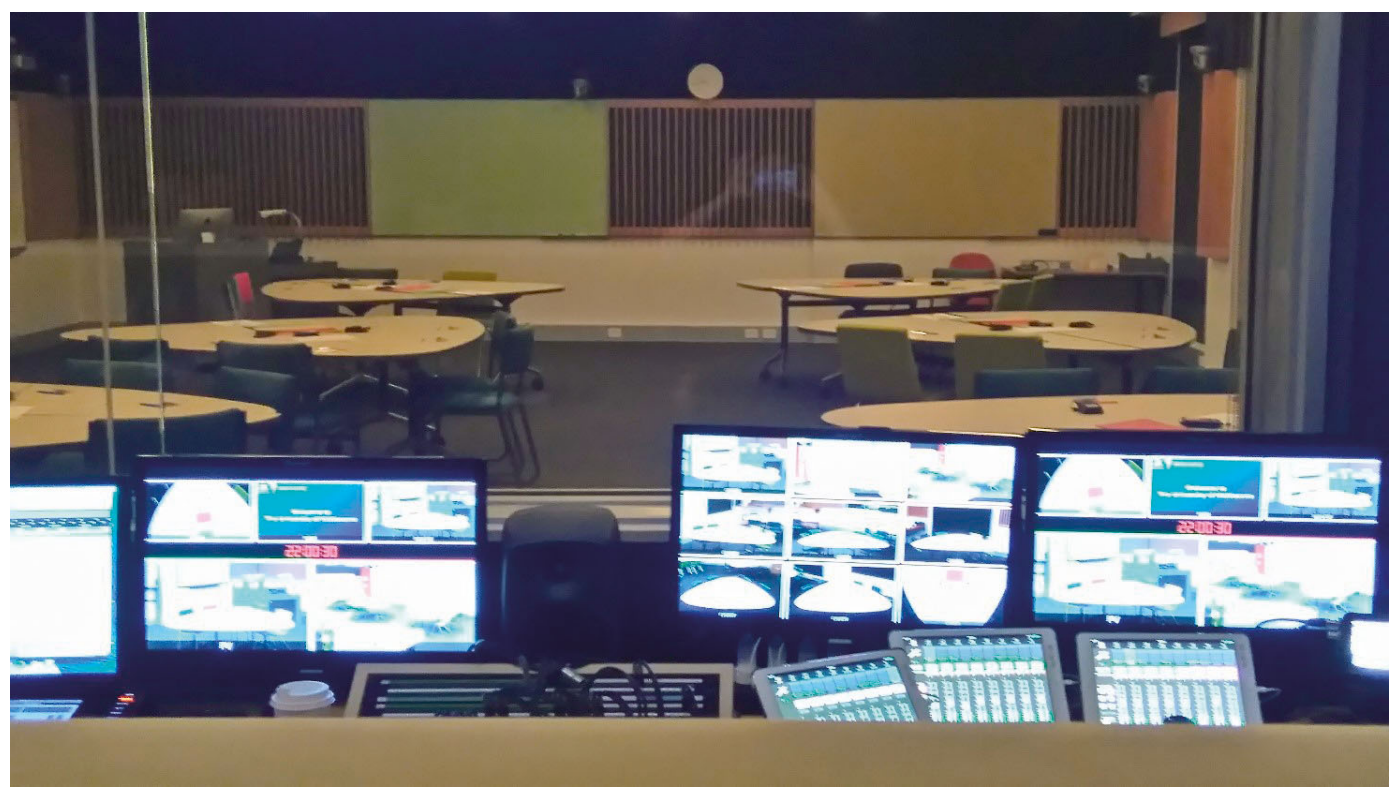

6 Se eventuelt https://www.youtube.com/watch?v=NoMkOybRu4g 


\section{Video som katalysator}

Video kan også ses som en katalysator, hvor deltagerne gennem brugen af video stimuleres til at eksperimentere med bestemte variabler i undervisningen. Det kan eksempelvis være lærerens arbejde med feedback, hvor der eksperimenteres med forskellige stilladserende tiltag som $\mathrm{fx}$ at opmuntre elever eller fremkomme med instruktioner. Helle Rønholt argumenterer ud fra et fænomenologisk perspektiv for, at "internaliseret viden som kommer til udtryk i praksis (praksisteori) er tavs viden, [som] kan erkendes ved at observere praksis og ikke ved at spørge praktikeren" (Rønholt, 2003, s. 108). Video kan netop anvendes til at etablere et refleksionsrum, hvor deltagere kan få øje på - og dermed mulighed for at eksplicitere perspektiver med henblik på at forandre praksis (Alrø \& Kristiansen, 1997; Bjørndal, 2014; Dirckinck-Holmfeld, 1997). Metoden stimuleret video genkaldelse (Busse \& Ferri, 2003; Dempsey, 2010) er et eksempel herpå. Videooptagelser hjælper informanterne med at genkalde sig en situation, og de anvendes aktivt i forbindelse med et interview. Det kan for eksempel ske ved, at informanterne fortæller, hvad de bemærker, når de ser en specifik undervisningssekvens. Igen henvises til et videoklip?

\section{Vi kommer ind i situationen umiddelbart efter, at matematiklæ- reren har gennemgået et fagligt stofområde. Eleverne sidder stille på deres pladser, mens læreren bevæger sig hen mod midten af rummet, mens hun finder et dias frem på sin iPad. \\ Matematiklæreren fortæller eleverne: "Det her, det er opgaverne, som skal laves - og det gælder om bare at få lavet så mange opga- ver som muligt. Men selvfølgelig skal man ikke suse hen over dem, så det/de ikke bliver ordentligt. Og spørg, hvis der er noget. Okay?"}

Mens læreren taler, begynder eleverne at finde deres ting frem.

I forbindelse med interviewene bliver informanterne spurgt: "Hvad bemærker du/I eksempelvis, når du/I ser følgende korte klip?"

I lærerinterviewet siger læreren:

Jamen, jeg vidste godt at ... den der formulering "at der skulle laves så mange opgaver som mulig", altså det er jo egentlig ikke 
det, jeg mener. Det det gælder om, det er og få trænet, det var det, jeg tænkte, at nu havde vi i så lang tid arbejdet med det konkrete og med borddiskussioner og så videre. Nu tænkte jeg, nu er det på sin ret, nu skal vi simpelthen have trænet de her opgaveløsninger også. Så det kom med også. ...jeg tænkte på det selv, da jeg havde sagt det, ...og det var også derfor, jeg sagde, at det gælder ikke om at jorde hen over opgaverne.

I elevgruppeinterviewet siger eleverne:

I: $\quad$ Hvad betyder det, når T hun siger, at I skal lave så mange opgaver som mulig?

Elev7: At vi skal gøre vores bedste.

I: $\quad$ I skal gøre jeres bedste. Det er sådan, du opfatter det ja.

Elev6: At man skal skynde sig, men alligevel også tænke sig om.

I: $\quad$ At skynde sig, men alligevel også tænke sig om. Hvad betyder det, når I får og vide, at man skal skynde sig og så tænke sig om? Hvad gør det ved jer?

Elev6: Da, der synes jeg, at når man regner opgaven, kan man godt regne den hurtig, men så bagefter hvis man regner den ud, så lige regne den bagfra, eller hvad man siger. Regne den igen.

Når forskeren vælger at bringe video ind i interviewsituationen, skaber han/ hun også en iscenesættelse af interviewet, der ansporer informanterne til at genkalde sig en situation. Men interviewspørgsmålene har en afgørende indflydelse på de data, som kommer ud af situationen. Samtidig har det også betydning, om det er forskeren eller informanten, der styrer afspilningen af sekvensen. Får informanten eksempelvis lov til at stoppe op og gense et særligt element, eller er det en fast sekvens, som de skal se, før de må tale (Busse \& Ferri, 2003).

\section{At få øje på undervisning}

Historisk set har den empiriske forskning i et opgør med en mere metafysisk videnskabstradition været knyttet til positivismens krav om videnskabelig eksakthed. Siden har forskere fra såvel den naturvidenskabelige som den 
humanistiske forskningstradition arbejdet empirisk. Den empiriske vending inden for uddannelsesforskningen trækker tråde til den empiriske eksperimentelle metode, som stammer fra den naturvidenskabelige forskning. Det betyder, at den type "løsninger", man søger gennem den videnskabelige praksis, især er forklaringer og objektive kendsgerninger. Dertil kommer, at denne type empiriske undersøgelser i dag er indlejret i en uddannelsespolitisk styringstænkning, der fokuserer på sammenligning og konkurrence. Men empirisk pædagogisk forskning behøver ikke være indlejret i denne videnskabsteoretiske tradition. Der er i Danmark også en anden tradition, nemlig en empirisk pædagogisk forskning, der er inspireret af en hermeneutisk og antropologisk tradition, og som i høj grad har didaktisk udvikling som sit sigtepunkt. Hvis vi mener, at der er brug for mange typer af empiriske undersøgelser i og af praksis, må vi tage udfordringen op og turde diskutere, hvordan man meningsfuldt kan lave undersøgelser for undervisning - altså undersøgelser, der har den dobbelte intentionalitet at bidrage til udvikling af undervisning i fag og teoriudvikling herom.

I denne artikel har vi zoomet ind på observation af undervisning. Ved at introducere til professor David Clarkes fire videometaforer har vi vist, at den måde, vi empirisk får øje på undervisning på, er stærkt knyttet til det videnskabsteoretiske ståsted, vi bedriver forskning fra. I vores optik gavnes den empiriske fagdidaktiske forskning ikke af en uproduktiv dikotomi mellem kvantitative og kvalitative forskningstilgange. Både kvantitative og kvalitative tilgange har styrker $\mathrm{i}$ forhold til at indfange undervisningens kompleksitet. Det interessante er, hvad man ønsker med sin forskning eller sine undersøgelser: vil man beskrive, forklare, forstå eller forandre? Sigtes på lokal eller global evidens? Udvikling eller sammenligning? Og hvorfra spørges der? Det kræver alt sammen, at den, der arbejder empirisk - både læreren og forskeren, skal være bevidst om det formaterende element i undersøgelsesdesign og dataarbejde. Ligesom læreren må besidde pædagogisk og didaktisk dømmekraft for at kunne kombinere sin teoretiske og almene viden med den konkrete, komplekse og vilde undervisningssituation, må den, der arbejder empirisk, udvikle metodisk dømmekraft - ikke mindst når det gælder undersøgelser af et vildt og komplekst genstandsfelt som undervisning. 
Hansen og Carlsen: Videoobservation

\section{Litteratur}

Alrø, H., \& Kristiansen, M. (1997). Mediet er ikke budskabet: video i observation af interpersonel kommunikation. I: Alrø, H., \& Dirckinck-Holmfeld, L. (Eds.), Videoobservation (73-99). Aalborg Universitetsforlag.

Amidon, E. (1966). Interaction Analysis - Recent Developments. Paper presented at the American Educational Research Association, Chicago, Illinois.

Biesta, G. (2011). God uddannelse i målingens tidsalder - etik, politik, demokrati. Århus N: Forlaget Klim.

Bjørndal, C.R.P. (2014). Videoobservation af lærerstuderendes praksis. UNGE PÆDAGOGER, 75(2), 60-69.

Brinkmann, S., \& Kvale, S. (2008). InterView Introduktion til et håndværk. København: Hans Reitzels Forlag.

Busse, A., \& Ferri, R.B. (2003). Methodological reflections on a three-step-design combining observation, stimulated recall and interview. Zentralblatt für Didaktik der Mathematik, 35(6), 257-264.

Clarke, D. (2010). Speaking in and about mathematics classrooms internationally: The technical vocabulary of students and teachers. Paper presented at the ACER Research Conferences.

Clarke, D. (2015). The Role of Video in Classroom Research - Window, Lens or Distorting Mirror? Paper presented at the AARE, University of Notre Dame, Fremantle WA.

Clarke, D., Mitchell, C., \& Bowman, P. (2009). Optimising the use of available technology to support international collaborative research in mathematics classrooms. I: Janik, T., \& Seidel, T. (Eds.), The power of video studies in investigating teaching and learning in the classroom (39-60). Berlin: Waxmann Publishing.

Clarke, D., Xu, L.H., Arnold, J., Seah, L.H., Hart, C., Tytler, R., \& Prain, V. (2011). Multi-theoretic approaches to understanding the science classroom. Paper presented at the ESERA 2011: ebook proceedings of the ESERA 2011 conference: Science learning and citizenship.

Dempsey, N.P. (2010). Stimulated recall interviews in ethnography. Qualitative sociology, 33(3), 349-367.

Dirckinck-Holmfeld, L. (1997). Video som medium i dialogforskning og organisatorisk læring. I: Alrø, H., \& Dirckinck-Holmfeld, L. (Eds.), Videoobservation (101-121). Aalborg Universitetsforlag.

Egelund, N., Aasen, A.M., Nordahl, T., \& Qvortrup, L. (2016). Resultater fra Kortlægningsundersøgelse i Svendborg Kommune 2015. 1. oplag, 1. udgave 2016.

Elliott, J. (2004). Making evidence-based practice educational. I: Thomas, G., \& Pring, R. (Eds.), Evidence-based practice in education (164-186). Berkshire: Open University Press.

Eraut, M. (2004). Practice-based evidence. I: Thomas, G., \& Pring, R. (Eds.), Evidence-based practice in education (91-101). Berkshire: Open University Press.

Fagligt løft af folkeskolen. (2013). Undervisningsministeriet.

Gjerløff, A.K., Jacobsen, A.F., Nørgaard, E., \& Ydesen, C. (2014). Da skolen blev sin egen: 19201970. Aarhus: Aarhus Universitetsforlag.

Hammersley, M. (2004). Some questions about evidence-based practice in education. I: Thomas, G. \& Pring, R. (Eds.), Evidence-based practice in education (133-149). Berkshire: Open University Press.

Hansen, R. (2016). På vej mod en målbevidst målstyret kompetenceorienteret matematikundervisning. Studier i læreruddannelse og -profession, 1(1), 28-54.

Helmke, A. (2013). Undervisningskvalitet og lærerprofessionalitet - diagnosticering, evaluering og udvikling af undervisningen. Frederikshavn: Dafolo Forlag.

Hermann, S. (2016). Hvor står kampen om dannelsen? Informations Forlag 
Jacobs, J., Garnier, H., Gallimore, R., Hollingsworth, H., Givvin, K., Rust, K., ... Manaster, A. (2003). TIMSS 1999 Video Study Technical Report: Volume 1: Mathematics Study. Washington DC: National Centre for Education Statistics, US Department of Education.

Jank, W., \& Meyer, H. (1997). Sambandet mellan didaktisk teorikunskap och handlingskompetens. I: Uljens, M. (Ed.), Didaktik (35-46). Lund: Studentlitteratur.

Krogstrup, H.K. (2006). Evalueringsmodeller: Systime Academic.

Krogstrup, H.K. (2011). Kampen om evidens. København: Hans Reitzels Forlag.

Lindblad, S., \& Sahlström, F. (2003). Klasserumsforskning. En oversigt med fokus på interaktion og elever. I: Bjerg, J. (Ed.), Pædagogik - en grundbog til et fag (243-276). København: Hans Reitzels Forlag.

Laeringsledelse.dk Lokaliseret d. 13. december 2016 på http://laeringsledelse.dk/?page_ $\mathrm{id}=221$

Oettingen, A.v. (2016). Almen didaktik: mellem normativitet og evidens. Kbh.: Hans Reitzel Forlag.

Olsen, J.V. (2016). Afsløring: Ingen evidens for, at læringsmålstyret undervisning virker. Lokaliseret d. 10. marts 2016 på https://www.folkeskolen.dk/583138/afsloering-ingen-evidens-for-at-laeringsmaalstyret-undervisning-virker

Qvortrup, L., Egelund, N., \& Nordahl, T. (2016). Resultater fra Kortlægningsundersøgelse for alle kommuner 2015. SAMMENFATNING. 1. oplag, 1. udgave 2016.

Raudaskoski, P. (2010). Observationsmetoder (herunder videoobservation). I:Brinkmann, S., \&Tanggaard, L. (Eds.), Kvalitative metoder: En grundbog: Hans Reitzels Forlag.

Rønholt, H. (2003). Didaktiske irritationer. I: Rønholt, H.,Holgersen, S.-E.,Fink-Jensen, K., \& Nielsen, A.M. (Eds.), Video i Pædagogisk Forskning (106-153). Forlaget Hovedland. Institut for Idræet, Københavns Universitet.

Sahlberg, P. (2012, 26.9.). How GERM is infecting schools around the world. The Washington Post. Lokaliseret 4. december 2016 på https://www.washingtonpost.com/blogs/ answer-sheet/post/how-germ-is-infecting-schools-around-the-world/2012/06/29/gJQAVELZAW_blog.html\#comments

Schmidt, E. (2016). Vi går glip af mangfoldighed, sanselighed og generøsitet. Lærerbladet(4), 9-11.

Skov, A.P. (2005). Forsøgs- og udviklingsarbejde i folkeskolen Uddannelseshistorie 2005: Syddansk Universitetsforlag.

Skovmand, K. (2016). Uden mål og med : Forenklede Fælles Mål? Kbh.: Hans Reitzels Forlag.

Skovmand, R. (1977). De frie skoletanker og reformerne i 1920'erne og 30'erne : om Ellen Nørgaards doktorafhandling »Lille barn, hvis er du? : en skolehistorisk undersøgelse over reformbestræbelser inden for den danske folkeskole i mellemkrigstiden.«. Årbog for dansk skolehistorie, 11, 90-105.

Thisted, J. (2010). Forskningsmetode i praksis: Munksgaard Danmark.

Thomas, G. (2004). Introduction: evidence and practice. I:Thomas, G., \&Pring, R. (Eds.), Evidence-based practice in education (1-18). Berkshire: Open University Press.

TIMSS-R Video Math Coding Manual. Lokaliseret 4. december 2016 på http://www.timssvideo.com/sites/default/files/Math\%20Coding\%20Manual.pdf

Uddannelses- og Forskningsministeriet. (2015). Bekendtgørelse om uddannelsen til professionsbachelor som lærer i folkeskolen. 